\title{
SENYAPAN PADA PRODUKSI UJARAN \\ DALAM PODCAST RUANG SANDI "CERITA MENGINSPIRASI MELLY GOESLAW PART 2"
}

\author{
Sofia Yasmin Suryadi ${ }^{1}$, Kholid Abdullah Harras ${ }^{2}$, Jatmika Nurhadi ${ }^{3}$ \\ ${ }^{1,2,3}$ Program Studi Bahasa dan Sastra Indonesia, \\ Fakultas Pendidikan Bahasa dan Sastra, Universitas Pendidikan Indonesia \\ ${ }^{1}$ sofiayasmin@upi.edu, ${ }^{2}$ kholid_harras@upi.edu, ${ }^{3}$ jatmikanurhadi@upi.edu
}

\begin{abstract}
Abstrak
Senyapan merupakan sebuah fenomena dalam produksi ujaran yang menarik untuk dikaji pada bidang psikolinguistik. Tujuan penelitian ini adalah mendeskripsikan bentuk-bentuk senyapan yang terjadi pada tuturan Sandiaga Uno dan Melly Goeslaw, serta mendeskripsikan penyebab terjadinya senyapan pada tuturan Sandiaga Uno dan Melly Goeslaw pada acara podcast yang terdapat pada saluran YouTube Podcast Ruang Sandi. Penelitian ini menggunakan metode penelitian deskriptif kualitatif. Sumber data yang diambil berasal dari situs web youtube.com saluran youtube "Podcast Ruang Sandi" episode "Cerita Menginspirasi Melly Goeslaw di Ruang Sandi Part 2". Subjek penelitian ini adalah Sandiaga Uno sebagai pembawa acara podcast dan Melly Goeslaw sebagai bintang tamu pada podcast tersebut. Objek penelitiannya adalah tuturan yang mengandung senyapan yang diujarkan oleh Sandi Uno dan Melly Goeslaw pada podcast episode tersebut. Pengumpulan data dilakukan dengan cara peneliti mengunduh video podcast yang akan dianalisis di situs youtube.com. Teknik pengumpulan data pada penelitian ini menggunakan teknik simak catat. Peneliti menyimak video podcast secara berulang kali dan mentranskrip ujaran-ujaran dari Sandi Uno dan Melly Goeslaw. Hasil penelitiannya ditemukan 24 tuturan yang mengandung senyapan, enam bentuk senyapan, dan lima penyebab terjadinya senyapan pada podcast tersebut.
\end{abstract}

Kata Kunci: Podcast; Psikolinguistik; Senyapan; Tuturan

\begin{abstract}
Pause is a phenomenon in speech production that is interesting to study in the field of psycholinguistics. The purpose of this study is to describe the forms of pause that occur in Sandiaga Uno and Melly Goeslaw's speech, as well as to describe the causes of pause in Sandiaga Uno and Melly Goeslaw's speech on podcasts available on the YouTube channel "Podcast Ruang Sandi". This research uses descriptive qualitative research methods. Sources of data taken are from the youtube.com website, the youtube channel name as "Podcast Ruang Sandi" episode "The Inspiring Story of Melly Goeslaw in the Sandi Room Part 2". The subject of this research is Sandiaga Uno as a podcast host and Melly Goeslaw as a guest star on the podcast. The object of research is a speech that contains pause uttered by Sandi Uno and Melly Goeslaw on the podcast episode. Data collection was carried out by researchers downloading video podcasts to be analyzed on the youtube.com site. The data collection technique in this study used the note-taking technique. The researcher listened to the video podcast repeatedly and transcribed the utterances of Sandi Uno and Melly Goeslaw. The results of his research found 24 utterances containing pauses, six forms of pauses, and five causes of pauses on the podcast.
\end{abstract}

Keywords: Podcast; Psycholinguistics; Pause; Speeches 


\section{PENDAHULUAN}

Keadaan dunia sekarang telah memasuki era digitalisasi. Era digitalisasi merupakan masa di mana semua kegiatan dan aktivitas manusia bisa dilakukan dengan cara modern yang lebih canggih dan praktis. Pada masa digitalisasi, segala aspek kehidupan manusia menjadi serba digital, terutama dalam aspek komunikasi. Pada aspek komunikasi, masyarakat menjalani aktivitas sehari-harinya dengan menggunakan perangkat digital, dimulai dari mengirim pesan melalui ponsel, diskusi secara daring, sampai belajar daring.

Di era digitalisasi, kegiatan diskusi atau wawancara sudah bisa dilakukan secara dalam jaringan (online). Salah satu kegiatan yang sedang marak dilakukan oleh masyarakat di era digitalisasi adalah siniar atau lebih dikenal dengan sebutan podcast. Podcast adalah file media digital yang berisi informasi (audio, video maupun informasi lain) yang diunggah dan diunduh melalui website atau portal tertentu ke komputer atau perangkat portabel (Indriastuti dan Saksono, 2014). Podcast merupakan sebuah media yang bisa digunakan dengan cara mendengar audio melalui komputer, laptop, dan HP android (Asmi dkk., 2019). Podcast/siniar adalah salah satu media pembelajaran yang menggunakan siaran audio yang dapat ditayangkan secara streaming (Sugatri, 2021). Podcast bisa menjadi media diskusi dan wawancara online yang efisien sehingga bisa menjadi media informasi yang efektif bagi masyarakat. Seiring berjalannya masa yang semakin modern, siaran podcast dapat dinikmati melalui berbagai platform streaming podcast, seperti spotify, joox, dan soundcloud. Podcast pun dapat ditayangkan melalui stasiun TV atau diunduh di situs youtube sehingga masyarakat bisa menonton dan mendengarkan podcast secara online.

Dari sekian banyak penyiar podcast di Indonesia, Sandi Uno atau Sandiaga Uno merupakan salah satu penyiar podcast fenomenal di Indonesia. Beliau merupakan Menteri Pariwisata dan Ekonomi Kreatif Indonesia yang dilantik oleh Presiden Jokowi sejak Desember 2020. Meski seorang menteri, Sandi Uno juga merupakan penyiar podcast yang aktif di situs YouTube dengan nama saluran youtube "Podcast Ruang Sandi". Dalam unggahan podcast-nya, Sandi Uno menghadirkan narasumber-narasumber yang penuh inovasi dan menginspirasi pemirsa. Salah satunya, pada episode "Cerita Menginspirasi Melly Goeslaw di Ruang Sandi Part 2" yang tentunya menghadirkan Melly Goeslaw sebagai narasumber podcast Sandi Uno pada episode tersebut. Episode tersebut merupakan lanjutan dari episode "Perdana! Di Ruang Sandi ada Melly Goeslaw, Cerita apa Sampai Nangis" pada saluran YouTube Podcast Ruang Sandi. Seperti yang masyarakat Indonesia ketahui, Melly Goeslaw merupakan seorang penyanyi terkenal di Indonesia. Namun, dalam episode podcast tersebut, Sandi Uno tidak meminta Melly Goeslaw untuk membagikan cerita seputar karier dalam dunia musiknya, melainkan Melly Goeslaw membagikan pengalamannya mengenai endorse gratis kepada UMKM dan usaha-usaha kecil di Indonesia di masa pandemi.

Seringkali ketika seseorang berbicara, terdapat hambatan yang terjadi saat ia mengujarkan sesuatu. Hal ini menandakan bahwa terdapat kesalahan atau ketidaklancaran saat memproduksi sebuah ujaran. Menurut Subyakto-Nababan (dalam Kurniawati, 2018) menyatakan tipe-tipe yang paling umum dalam ketidaklancaran produksi ujaran antara lain berupa keraguan, jeda, pembetulan, permulaan yang salah, pengulangan, kegagapan, dan lidah keseleo. Pada penelitian ini, akan menganalisis satu bentuk ketidaklancaran saat berujar, yaitu senyapan yang terjadi pada tuturan Sandi Uno dan Melly Goeslaw. Senyapan dalam sebuah tuturan dapat menyimpulkan proses mental seseorang saat ia mengujarkan sesuatu. Ada beberapa bentuk senyapan di antaranya meliputi senyapan 
diam, senyapan terisi berupa bunyi, kata, dan kalimat, pengulangan, pemanjangan, parenthetical remark, false start, dan kombinasi senyapan.

Pengujaran yang ideal dapat terwujud dalam suatu bentuk ujaran yang lancar, kata- katanya terangkai rapi, diujarkan dalam suatu urutan yang tak terputus, meski terdapat senyapan, maka senyapan itu terletak dalam konstituen yang tepat (Dardjowidjojo, 142:2012). Pada praktiknya, tidak semua orang dapat berujar dengan ideal. Meski seseorang mengusai topik pembicaraan, tetapi selalu terdapat senyapansenyapan yang terjadi pada ujaran tersebut. Pada saat melontarkan pertanyaan kepada Melly Goeslaw, Sandi Uno tampak menuturkan ujaran dengan cukup lancar tidak tergesagesa. Namun, pada setiap ucapan yang ia ujarkan, terdapat senyapan-senyapan yang muncul pada ujaran tersebut. Begitu pula, dengan Melly Goeslaw, ia menjawab setiap pertanyaan dengan cukup lancar, tetapi seringkali terputus-putus, banyak jeda berupa senyapan ketika menjawab pertanyaan yang dilontarkan oleh Sandi Uno. Pada waktu tertentu, penutur perlu berhenti sejenak untuk menentukan atau menemukan satuan kebahasaan yang tepat, yang sesuai dengan maksud yang diinginkannya (Kurniawati, 2018). Senyapan pada umumnya terjadi karena faktor ketidaksengajaan. Mengenai fenomena senyapan tersebut, tentunya terdapat beberapa penyebab mengapa senyapan itu terjadi pada setiap tuturan mereka dan apa saja bentuk-bentuk senyapan yang terjadi pada setiap ujaran mereka. Hal ini harus dikaji lebih dalam guna mendapatkan informasi mengenai senyapan dalam produksi ujaran dalam disiplin ilmu psikolinguistik.

Penelitian tentang senyapan dalam produksi ujaran termasuk ke dalam kajian psikolinguistik. Psikolinguistik merupakan kajian yang menerangkan hakikat struktur bahasa, bagaimana struktur ini diperoleh, digunakan pada waktu bertutur, dan pada waktu memahami kalimat-kalimat dalam pertuturan itu (Busro, 2016). Kajian psikolinguistik merupakan gabungan dari ilmu psikologi dan linguistik. Dardjowidjojo (7:2012) menyatakan psikolinguistik mempelajari empat topik utama, yaitu komprehensi, produksi, landasan biologis dan neurologis, serta pemerolehan bahasa.

Penelitian tentang kesalahan produksi ujaran termasuk fenomena senyapan merupakan penelitian yang sudah pernah dilakukan sebelumnya. Dian Lufia Rahmawati meneliti tentang senyapan yang diujarkan oleh Iwan Fals pada acara talkshow Kick Andy. Rahmawati menyatakan senyapan terjadi selama 30 detik atau sekitar 23,8\% dari waktu bicaranya selama 126 detik. Selain itu, terjadi dua jenis senyapan yang terjadi yaitu senyapan diam dan senyapan terisi (Rahmawati, 2014). Selain itu, penelitian mengenai kesalahan dalam produksi ujaran terdapat pada penelitian Dian Etikasari dkk. yang meneliti terkait senyapan pada tuturan Presiden Jokowi dalam wawancara di sebuah stasiun TV. Hasil penelitiannya adalah senyapan yang terjadi pada tuturan Presiden Jokowi meliputi dua jenis senyapan, yakni senyapan terisi, senyapan pemanjangan, senyapan kombinasi, senyapan pengulangan, senyapan false start, dan senyapan diam. Kemudian ditemukan juga tujuh penyebab senyapan yang terjadi pada Presiden Jokowi dalam wawancara di sebuah stasiun TV tersebut (Etikasari dkk., 2021). Dapat disimpulkan bahwa kedua penelitian tersebut ada yang bertujuan meneliti durasi waktu senyapan dalam sebuah tuturan, bentuk-bentuk senyapan, dan penyebab terjadinya senyapan dalam suatu tuturan. Perbedaan kedua penelitian tersebut dengan penelitian ini terletak pada subjek penelitian. Subjek penelitian pada penelitian ini menggunakan subjek penelitian seorang podcaster sekaligus Menteri Pariwisata dan Ekonomi Kreatif Indonesia dan salah seorang penyanyi terkenal Indonesia. Selain itu, media penelitian podcast cenderung masih jarang dilakukan. 
Berdasarkan latar belakang yang diuraikan, penelitian ini akan mengkaji tentang senyapan yang terjadi pada tuturan Sandiaga Uno sebagai penyair podcast sekaligus Menteri Parekraf Indonesia dan Melly Goeslaw sebagai penyanyi Indonesia. Penelitian ini bertujuan untuk 1) Mendeskripsikan bentuk-bentuk senyapan yang terjadi pada tuturan Sandiaga Uno dan Melly Goeslaw, 2) Mendeskripsikan penyebab terjadinya senyapan pada Sandiaga Uno ketika memberikan pertanyaan dan merespon tanggapan kepada Melly Goeslaw sebagai narasumber, serta pada Melly Goeslaw ketika menjawab pertanyaan dan menanggapi pertanyaan dari Sandiaga Uno selaku pembawa acara.

\section{METODE PENELITIAN}

Penelitian ini menggunakan metode penelitian deskriptif kualitatif. Sumber data yang diambil berasal dari situs web youtube.com, saluran youtube "Podcast Ruang Sandi" episode "Cerita Menginspirasi Melly Goeslaw di Ruang Sandi Part 2". Subjek penelitian ini adalah Sandiaga Uno sebagai pembawa acara podcast dan Melly Goeslaw sebagai bintang tamu pada podcast tersebut. Objek penelitiannya adalah tuturan yang mengandung senyapan yang diujarkan oleh Sandi Uno dan Melly Goeslaw pada podcast episode tersebut.

Pengumpulan data dilakukan dengan cara mengunduh video podcast yang akan dianalisis di situs youtube.com. Teknik pengumpulan data pada penelitian ini menggunakan teknik simak catat. Peneliti menyimak video podcast secara berulang kali dan mentranskrip ujaran-ujaran dari Sandi Uno dan Melly Goeslaw. Pada tahap analisis data, peneliti menggunakan metode dekskriptif yang merupakan penelitian dengan cara mengumpulkan data yang berupa kata-kata, gambar, dan bukan angka (Moleong dalam Susilowati, 2017). Peneliti mengidentifikasi dan mendeskripsikan apa saja bentuk-bentuk senyapan yang dihasilkan dari ujaran Sandi Uno dan Melly Goeslaw, serta mendeskripsikan apa saja penyebab senyapan tersebut terjadi pada ujaran Sandi Uno dan Melly Goeslaw.

\section{HASIL DAN PEMBAHASAN}

Hasil dari penelitian ini adalah 1) Deskripsi bentuk-bentuk senyapan pada tuturan Sandiaga Uno dan Melly Goeslaw dalam acara Podcast Ruang Sandi. 2) Deskripsi penyebab terjadinya senyapan yang dituturkan oleh Sandiaga Uno dan Melly Goeslaw dalam acara Podcast Ruang Sandi.

\section{Bentuk-Bentuk Senyapan pada Tuturan Sandiaga Uno dan Melly Goeslaw dalam Acara Podcast Ruang Sandi}

\section{Senyapan Diam}

Kesenyapan diartikan sebagai suatu jeda dalam tuturan yang memisahkan dengan tuturan selanjutnya (Etikasari dkk., 2021). Senyapan diam adalah ketika penutur berhenti sejenak dan diam saja. Menurut Mayasari dari seorang pembicara yang mengalami senyapan diam, kalimatnya akan dilanjutkan kembali setelah menemukan kata-kata yang dicari (Mayasari, 2015). Hal ini dialami oleh Sandiaga Uno dan Melly Goeslaw saat menuturkan obrolannya pada acara podcast di saluran youtube "Podcast Ruang Sandi". Berikut adalah data dari ujaran yang mengandung senyapan diam: (Keterangan: tanda "//" merupakan tanda jeda saat senyapan diam terjadi)

1. Melly Goeslaw: iya ada banyak sih semuanya hampir semuanya, jadi dm saya penuh banget sama pedagang-pedagang//tapi ya alhamdulillah ya jadi banyak temen gitu 
2. Melly Goeslaw: ...memang promosi itu//harus//dan memang//publik figurlah yang mesti bantu untuk mereka promosi....

3. Melly Goeslaw: kalau idenya sih datangnya kapan aja ya cuma pas sendiri itu biasanya halunya itu//makin//meningkat gitul/ dan kebanyakan kalau diliat videovideol/yang//aku nyanyi-nyanyi sendiri gitu seolah-olah show, seolah-olah talkshow, itu betul-betul sendiri, mas Anto gatau, anak-anak gatau, karena kalau ada kalau mas Anto tau nanti dia ngintip ...

4. Melly Goeslaw: ...jadi udahlah kita lucu-lucuan aja nggak pake konsep, ngobrol gitu aja gelinding pake bahasa sunda gada subtittle udah gitu aja tapi//yaa//lumayan...

5. Sandi Uno: ...jadi distract malah ya kalau ada mas Anto sama ini//nah//saya lihat yang juga sama hedi yunus...

6. Sandi Uno: ...Sekarang dial/tadinya omsetnya 800 ribu perhari ini sudah 3 kali lipat....

7. Sandi Uno: ...kalau kita ngeliat YouTube lucu banget nih yutubnya teh meli ini keknyal/sumber idenya ni nggak abis-abis saya mo tanya tu biasanya ide-ide datang ke seorang melly goeslaw itu...

8. Sandi Uno: saya membina 400.00 umkm di oke ocel/70\% dipukul rata mereka sulit banget. Jadi ini//nemuin cerita-cerita kayak//kreniss yang naik 20\% disaat pandemi ini bener-bener truly inspiring

Pada tuturan 1 sampai 4 merupakan tuturan dari Melly Goeslaw ketiak menjawab pertanyaan-pertanyaan dari Sandi Uno. Tuturan 1 sampai 3, senyapan diam terdapat pada tengah kalimat, sedangkan tuturan 4 terjadi pada akhir kalimat. Pada tuturan 1, senyapan terjadi setelah Melly Goeslaw mengatakan sebuah kata nomina yaitu pedagangpedagang, kemudian dilanjut dengan mengatakan kata tapi. Pada tuturan 2, senyapan diam terjadi tiga kali. Dalam tuturan 2, Melly Goeslaw tampak agak kesulitan mencari kata yang pas untuk menyambung tuturannya. Senyapan diam pada tuturan 3 terjadi sampai lima kali. Pada tuturan 3, selain Melly Goeslaw tampak kesulitan mencari kata yang pas untuk melanjutkan tuturan, Melly Goeslaw juga tampak ragu-ragu untuk mengujarkan pernyataannya. Pada tuturan 4, senyapan diam terjadi di akhir kalimat setelah Melly Goeslaw mengujarkan kata tapi. Pada tuturan 4 pula, Melly Goeslaw terlihat memikirkan kata yang tepat untuk melanjutkan tuturannya.

Tuturan 5, 6, dan 7 merupakan tuturan dari Sandiaga Uno. Pada tuturan 5, senyapan diam terjadi saat setelah Sandi Uno mengujarkan kata ini. Pada tuturan 5, Sandi Uno tampak merasa ragu untuk mengalihkan topik pembicaraan sehingga terjadi senyapan. Pada tuturan 6, setelah Sandi Uno mengatakan pronomina dia, Sandi Uno tampak merasa bingung dan sulit mencari kata yang tepat untuk tuturan selanjutnya. Kesulitan mencari kata yang tepat untuk tuturan selanjutnya juga terjadi pada tuturan Sandi Uno yang ke tujuh.

\section{Senyapan Terisi Berupa Bunyi}

Pada podcast tersebut, senyapan terisi berupa bunyi lebih sering muncul pada tuturan Sandi Uno. Hampir pada setiap tuturan, Sandi Uno mengalami senyapan yang ditandai dengan bunyi "e...". Senyapan terjadi saat Sandi Uno memulai acara podcast, menanggapi tanggapan dari narasumber, menyalurkan pendapatnya, hingga saat penutupan acara. Senyapan ini terjadi dikarenakan Sandi Uno merasa gugup dan kesulitan dalam mendapatkan kata yang dicari. Berikut adalah data senyapan terisi berupa bunyi dari tuturan Sandi Uno: 
9. Sandi Uno: Dan ini balik lagi ke UMKM karena ini bener-bener menginspirasi e... saya lihat memang dari yang diendorse eu... kita pengen tahu nih respons UMKMUMKM nya eu... ada nggak yang dm atau curhat eu... sama teh Melly soal perubahan yang dirasakan setelah diendorse oleh teh melly

10. Sandi Uno: Impowering... eu... dan beyond charity. Biasanya kalau charity kita bagibagi donasi, tunai, sembako emang ada yang harus kita bantu seperti itu...

11. Sandi Uno: Nah memang, eu ... ada beberapa pilar pertama pilar itu pelatihan...

12. Sandi Uno: ...jadi saya ingin berbagi eu... langkah pas ya biasanya di UMKM ini yang dibawah binaan kita eu... yaitu pasnya pasti akan sukses insya allah gitu...

13. Sandi Uno: Terus bagaimana seleranya itu diperhatikan, cek dulu sama eu... keluarga enak ga enak ga gitu eu... dan ini pelatihan yang paling penting.

14. Sandi Uno: Nah ini yang disaat pandemi ini euu susah euu... susu jahe eu... Pak Budi itu di Kemang, susu jahe raisa eu.... Seperti yang eu... Mba Melly sampaikan dia nggak naikin harga...

15. Sandi Uno: Dia lakukan dengan euu... digital dia coba pasarkan, ternyata allah berikan begtiu banyak kemudahan buat dia...

16. Sandi Uno: Nah untuk pendengar eu... podcast ruang sandi boleh ga nih teh Melly nyanyi dikit untuk eu... menghibur kita nih.

Selanjutnya, senyapan terisi berupa bunyi "eu" terjadi pada tuturan Melly Goeslaw saat menuturkan pernyataannya mengenai pernikahan perak dengan suaminya. Melly Goeslaw nampak kesulitan dalam menemukan kata yang tepat untuk melanjutkan penuturannya. Berikut tuturannya:

17. Melly Goeslaw: Itu adalah konser eu... pernikahan perak aku sama Mas Anto dan 25 tahun berkarir...

\section{Senyapan Terisi Berupa Kata}

Dalam podcast ini, tuturan yang mengandung senyapan terisi berupa kata terdapat pada tuturan Melly Goeslaw saat menuturkan pendapat tentang solusi UMKM agar sejahtera kala pandemi Covid-19. Senyapan terisi berupa kata ditandai dengan kata "apa sih" yang menandakan bahwa Melly Goeslaw saat menuturkan ujaran tersebut tampak lupa dan tidak konsentrasi terhadap apa yang dibicarakan. Berikut adalah data tuturan senyapan terisi berupa kata:

18. Melly Goeslaw: lebih di turunin lagi apa sih namanya bukan, bukan kualitas tapi mungkin kayaknya biasanya bungkusnya pake... bahan ini diturunin gitu, harganya dimurahin, kayak gitu, tanpa mengurangi kualitas dari rasanya.

\section{Senyapan Pemanjangan}

Senyapan pemanjangan terjadi pada satu tuturan Sandi Uno pada akhir acara podcast. Pada tuturan tersebut, Sandi Uno menyampaikan salam kepada suami Melly Goeslaw. Senyapan pemanjangan terjadi pada kata "dan" kemudian dilanjutkan dengan kata "Teh Melly". Jika dipraktikkan, maksud dari senyapan panjang tersebut adalah kata "dan" akan berbunyi seperti "daann". Hal tersebut menandakan bahwa senyapan pemanjangan yang terjadi pada tuturan Sandi Uno menyatakan bahwa Sandi Uno tidak konsentrasi terhadap apa yang dibicarakannya. Berikut adalah tuturan yang mengandung senyapan pemanjangan:

19. Sandi Uno: Salam untuk Mas Anto sukses terus untuk potret dan (dipanjangkan) teh Melly Goeslaw terus berkarya dan eu... memberikan begitu banyak inspirasi nuansa positif bagi bangsa. 


\section{Senyapan Pengulangan}

Pada saat Melly Goeslaw sedang menceritakan pengalamannya meng-endorse UMKM Indonesia, terdapat beberapa tuturan Melly Goeslaw yang mengandung senyapan pengulangan. Senyapan pengulangan adalah sejenis senyapan yang terjadi dengan mengulang suatu kata atau frasa. Tuturan yang mengandung senyapan pengulangan dapat dilihat pada tuturan 20 dan 21 berikut: (Senyapan pengulangan ditandai dengan kata yang bergaris bawah)

20. Melly Goeslaw: ...paling nggak kalau misalkan cari apa-apa oh terus, akuuu ..., aku simpen semuanya di highlight, di highlight, jadi kalau instastory 24 jam kehapus, aku simpen di highlight ...

21. Melly Goeslaw: ...terus kurang lucu karena ... karena akunya jadi ... jadi ... jaim...

Pada tuturan 20, Melly Goeslaw mengulang kata "di highlight" sebagai kata keterangan yang terletak di tengah kalimat. Selanjutnya pada tuturan 21, Melly Goeslaw juga melakukan tuturan yang mengandung senyapan pengulangan yang ditandai dengan mengulang kata "karena" dan kata "jadi".

\section{Senyapan Kombinasi}

Selain bentuk-bentuk senyapan yang telah dideskripsikan di atas, terdapat pula senyapan kombinasi yang muncul pada acara podcast tersebut. Senyapan kombinasi merupakan senyapan yang memiliki lebih dari satu bentuk senyapan pada satu tuturan. Pada acara podcast ini, terdapat tiga tuturan yang mengandung senyapan kombinasi. Berikut adalah data senyapan kombinasi pada "Podcast Ruang Sandi":

22. Sandi Uno: Kenapa pilih endorsement...eu sebagai bentuk bantuan? Tadi... Teh Melly udah cerita sedikit tapi passionnya tuh ada ... dimana eu pada saat pandemi ini yang membawa Teh Melly berpikir ini endorsement yang tepat banget?

23. Melly Goeslaw: ... nah ini gimana caranya panjang... terus dia juga ada ... ada yang terkait sama dia pegawainya atau apa juga ikut gausah di PHK gitu berarti dagangannya atau produknya euu... bisnisnya harus berjalan

24. Sandi Uno: Tapi ini luar biasa, meee, udah... mungkin ratusan lagu yang dikarang oleehh Teh Melly dan puluhan yang sudah jadi hits. eu luar biasa ringkasan kita tanpa terasa kita sudah menuju ke closing, tapi sebelum mengakhiri obrolan kita yang sangat menginspirasi ini saya pengen nanya mmm... tentang Teh Melly kan ini pandemi insya allah kalau sesuai dengan prediksi pemerintah...

Pada tuturan 22, terdapat tuturan Sandi Uno yang sedang memberikan pertanyaan kepada Melly goeslaw tentang endorsement kepada UMKM. Tuturan 22 termasuk senyapan kombinasi karena mengandung beberapa bentuk senyapan, di antaranya adalah pertama senyapan terisi yang ditandai dengan kata "endorsement...eu" dan kata "dimana eu pada". Kedua terdapat senyapan diam yang terletak pada kata "tadi" dan "ada". Pada tuturan 24 juga merupakan tuturan Sandi Uno. Senyapan kombinasi pada tuturan 24 terjadi di awal dan tengah ujaran. Senyapan kombinasi tuturan 24 diantaranya adalah senyapan terisi berupa bunyi dan senyapan terisi berupa kata yang ditandai oleh kata "mee...udah..." dan frasa "eu luar biasa".

Tuturan 23 merupakan tuturan dari Melly Goeslaw yang mengandung senyapan kombinasi. Senyapan kombinasi yang terdapat dalam tuturan 23 diantaranya adalah senyapan diam yang ditandai oleh kata "panjang", senyapan pengulangan yang ditandai dengan kata "ada", dan senyapan terisi berupa bunyi yang ditandai oleh kata "eu...bisnisnya". Jadi terdapat tiga kombinasi senyapan yang ada dalam tuturan 23 . 


\section{Penyebab Terjadinya Senyapan pada Tuturan Sandiaga Uno dan Melly Goeslaw dalam Acara Podcast Ruang Sandi}

Menurut Mayasari (2015) dalam proses berbicara, psikologi seseorang dapat tersentuh sehingga memunculkan beberapa efek psikologi tertentu, seperti tergesa-gesa, grogi, humor (lelucon), ketidaksengajaan, dan tidak konsentrasi. Sementara menurut Rahmawati (2014) alasan-alasan orang mengalami senyapan di antaranya adalah 1) karena terlanjur mulai dengan ujarannya, sementara ia belum siap untuk menuturkan kalimatnya, 2) lupa akan kata-kata yang ia perlukan, dan 3) ia harus berhati-hati dalam memilih kata agar dampak bagi para pendengar terkesan tidak menyakitkan atau menghebohkan.

Beberapa alasan penyebab terjadinya senyapan pada tuturan Sandiaga Uno dan Melly Goeslas pada acara Podcast Ruang Sandi, di antaranya adalah sebagai berikut:

\section{Mengambil Nafas}

Suatu senyapan bisa terjadi karena terdapat pengamibilan nafas yang berada di tengah-tengah ujaran. Berikut ini terdapat ujaran-ujaran yang mengandung senyapan yang dikarenakan oleh pengambilan nafas penutur:

1. Sandi Uno: Dan ini balik lagi ke UMKM karena ini bener-bener menginspirasi $\underline{\text { e... }}$ saya lihat memang dari yang diendorse eu... kita pengen tahu nih respons UMKMUMKM nya eu... ada nggak yang dm atau curhat eu... sama teh Melly soal perubahan yang dirasakan setelah diendorse oleh teh melly

2. Melly Goeslaw: iya ada banyak sih semuanya hampir semuanya, jadi dm saya penuh banget sama pedagang-pedagang//tapi ya alhamdulillah ya jadi banyak temen gitu

3. Sandi Uno: saya membina 400.00 umkm di oke ocel/70\% dipukul rata mereka sulit banget. Jadi ini//nemuin cerita-cerita kayak//kreniss yang naik 20\% disaat pandemi ini bener-bener truly inspiring

4. Sandi Uno: ...kalau kita ngeliat YouTube lucu banget nih yutubnya teh meli ini keknyal/sumber idenya ni nggak abis-abis saya mo tanya tu biasanya ide-ide datang ke seorang melly goeslaw itu...

5. Sandi Uno: ...jadi distract malah ya kalau ada mas Anto sama ini//nah//saya lihat yang juga sama hedi yunus...

\section{Kehati-hatian dalam Memilih Kata}

Seseorang jika berbicara di depan umum pasti memperhatikan kata-kata apa yang akan diujarkan sehingga tidak terjadi disinformasi atau timbulnya perkataan yang menyakitkan para pendengar. Berikut ini merupakan tuturan dari Sandi Uno dan Melly Goeslaw dalam acara Podcast Ruang Sandi:

6. Sandi Uno: Kenapa pilih endorsement...eu sebagai bentuk bantuan? Tadi... Teh Melly udah cerita sedikit tapi passionnya tuh ada ... dimana eu pada saat pandemi ini yang membawa Teh Melly berpikir ini endorsement yang tepat banget?

7. Sandi Uno: Impowering... eu... dan beyond charity. Biasanya kalau charity kita bagibagi donasi, tunai, sembako emang ada yang harus kita bantu seperti itu...

8. Melly Goeslaw: ...memang promosi itu//harus//dan memang//publik figurlah yang mesti bantu untuk mereka promosi....

9. Sandi Uno: ...jadi saya ingin berbagi eu... langkah pas ya biasanya di UMKM ini yang dibawah binaan kita eu... yaitu pasnya pasti akan sukses insya allah gitu... 
10. kalau idenya sih datangnya kapan aja ya cuma pas sendiri itu biasanya halunya itu//makin//meningkat gitu/l dan kebanyakan kalau diliat video-video//yang//aku nyanyi-nyanyi sendiri gitu seolah-olah show, seolah-olah talkshow, itu betul-betul sendiri, mas Anto gatau, anak-anak gatau, karena kalau ada kalau mas Anto tau nanti dia ngintip ...

\section{Lupa akan Kata-Kata yang Diperlukan}

Lupa merupakan salah satu hal yang wajar ketika menuturkan ujaran. Lupa merupakan salah satu penyebab terjadinya senyapan dalam ujaran. Kutipan berikut merupakan senyapan yang terjadi pada tuturan Melly Goeslaw karena lupa mengingat kata-kata yang diperlukan:

11. Melly Goeslaw: lebih di turunin lagi apa sih namanya bukan, bukan kualitas tapi mungkin kayaknya biasanya bungkusnya pake... bahan ini diturunin gitu, harganya dimurahin, kayak gitu, tanpa mengurangi kualitas dari rasanya...

12. Melly Goeslaw: Itu adalah konser eu... pernikahan perak aku sama Mas Anto dan 25 tahun berkarir...

\section{Mencari kata-kata yang tepat untuk disampaikan}

Pada tuturan-tuturan di bawah ini merupakan senyapan yang terjadi karena penutur mencari kata-kata yang tepat agar ujaran lebih enak didengarkan.

13. Sandi Uno: Terus bagaimana seleranya itu diperhatikan, cek dulu sama eu... keluarga enak ga enak ga gitu eu... dan ini pelatihan yang paling penting...

14. Sandi Uno: Nah ini yang disaat pandemi ini euu susah, euu... susu jahe eu... Pak Budi itu di Kemang, susu jahe raisa eu.... Seperti yang eu... Mba Melly sampaikan dia nggak naikin harga...

15. Sandi Uno: ...Sekarang dial/tadinya omsetnya 800 ribu perhari ini sudah $3 k a l i$ lipat....

16. Melly Goeslaw: ...jadi udahlah kita lucu-lucuan aja nggak pake konsep, ngobrol gitu aja gelinding pake bahasa sunda gada subtittle udah gitu aja tapi//yaa//lumayan...

17. Sandi Uno: Salam untuk Mas Anto sukses terus untuk potret dan (dipanjangkan) teh Melly Goeslaw terus berkarya dan eu... memberikan begitu banyak inspirasi nuansa positif bagi bangsa.

18. Sandi Uno: Nah memang, eu... ada beberapa pilar pertama pilar itu pelatihan

\section{Adanya Kekeliruan Tuturan}

Senyapan dapat terjadi karena adanya kekeliruan tuturan seseorang. Pada tuturan Sandi Uno berikut, senyapan yang ditandai dengan kata "mee..udah.." adalah senyapan yang terjadi karena adanya kekeliruan tuturan. Sebelum kata "udah" diucapkan, Sandi Uno sempat mengujarkan kata yang tidak sempurna pengujarannya yaitu pada kata "me...". Sehingga hal ini menyebabkan senyapan pada tuturan Sandi Uno tersebut.

Sandi Uno: Tapi ini luar biasa, meee, udah... mungkin ratusan lagu yang dikarang oleehh Teh Melly dan puluhan yang sudah jadi hits...

\section{SIMPULAN}

Senyapan merupakan sebuah fenomena dalam produksi ujaran yang menarik untuk dikaji pada bidang psikolinguistik. Berdasarkan hasil penilitian, ditemukan 24 tuturan yang mengandung senyapan dalam acara Podcast Ruang Sandi. Dari 24 tuturan 
tersebut, dikategorikan menjadi enam bentuk senyapan, antara lain senyapan diam, senyapan terisi berupa bunyi, senyapan terisi berupa kata, senyapan pengulangan, senyapan pemanjangan, dan senyapan kombinasi. Kemudian, terdapat lima penyebab terjadinya senyapan dalam acara Podcast Ruang Sandi, di antaranya adalah mengambil nafas, kehati-hatian dalam memilih kata, lupa akan kata-kata yang diperlukan, mencari kata-kata yang tepat untuk disampaikan, dan adanya kekeliruan dalam tuturan.

\section{DAFTAR PUSTAKA}

Asmi, A. R., Dhita, A, N., \& Suproyanto. (2019). Pengembangan media pembelajaran audio berbasis podcast pada materi sejarah lokal di Sumatera Selatan. Historia: Jurnal Pendidik dan Peneliti Sejarah, 3(1), 49-56.

Busro, M. (2016). Kajian dalam psikolinguistik, perangkat penelitian, strategi, dan penggunaan metode penelitian. Journal Al Hikmah, 6(2), 209-218.

Dardjowidjojo, S. (2012). Psikolinguistik: Pengantar pemahaman bahasa manusia. Jakarta: Yayasan Pustaka Obor Indonesia

Etikasari, D., Nurjanah, E., \& Mulyaningtyas, R. (2021). Senyapan tuturan Presiden Joko Widodo dalam wawancara eksklusif di Kompas TV. Jurnal Ilmiah SEMANTIKA, 2(02), 41-51

Indriastuti, F., \& Saksono, W. T. (2014). Podcast sebagai sumber belajar berbasis audio audio podcasts as audio-based learning resources. Jurnal Teknodik, 18(3), 304314.

Kurniawati, W. (2018). Senyapan dalam tuturan berbahasa Indonesia: Studi terhadap tuturan pada "Debat Pilkada DKI 2017". Widyaparwa, 46(1), 75-90.

Mayasari, I. (2015). Senyapan dan kilir lidah dalam produksi ujaran (kajian psikolinguistik). Deiksis, 7(02), 123-132.

Rahmawati, D. L. (2014). Senyapan pada ujaran Iwan Fals di acara Talkshow Kick Andy "Akhirnya Iwan Fals Bicara". Anterior Jurnal, 14(1), 71-80.

Sugatri, M. (2021). Peranan siniar sebagai media pembelajaran sosiologi di masa pandemi. Ideguru: Jurnal Karya Ilmiah Guru, 6(1), 58-66.

Susilowati. (2017). Kegiatan humas indonesia bergerak di Kantor Pos Depok II dalam meningkatkan citra instansi pada publik eksternal. Jurnal Komunikasi, 8(2), 4754. 